\title{
Diffusion of Quality Standards in the Hospitality Sector
}

\begin{abstract}
Purpose: The aim of this study is to compare the diffusion of certifications under two quality management systems (QMSs) in the tourism sector in Spain: (i) the generic ISO 9001 international standard; and (ii) the Spanish industry-specific 'Q' standard.

Methodology: The study pursues this objective by comparing the logistic curves of dissemination of certifications under the two standards using data obtained from official sources. This analysis is complemented with qualitative data from several case studies of Spanish hotels and restaurants.

Findings: The results show that the two standards are at different stages of diffusion. Moreover, certification under the 'Q' standard in Spain is increasing at the expense of the ISO 9001 international standard.

Originality: The main contribution of this study is that it is one of the first to analyse the dissemination of quality standards in a specific sector. The findings are thus of considerable importance in extending knowledge of quality management in the tourism sector.
\end{abstract}

Key words: diffusion, ISO 9001, 'Q' Spanish standard, quality, hospitality

Category: Research paper 


\section{Introduction}

The proliferation of management system standards (MSSs) in recent years reflects the importance that businesses now attach to improving the efficiency of their management systems. Further evidence of this phenomenon is the acceleration in the number of certifications being sought in accordance with the standards of the International Organisation for Standardisation (ISO), especially the ISO 9001 standard for quality management systems (QMSs) and the ISO 14001 standard for environmental management systems (EMSs). According to the latest ISO Survey (ISO, 2009), up to the end of December 2008 there had been 982,832 ISO 9001 certificates issued to organisations in 176 countries (representing a 3\% growth from 2007), and 188,815 ISO 14001 registrations in 155 countries (22\% more than in 2007). Other examples of standardised management systems that have been increasingly implemented in recent years include those that address occupational health and safety (for example, OHSAS 18001), corporate social responsibility (SA 8000 and AA 1000), information security (ISO 27001), and customer satisfaction (ISO 10000 series).

The diffusion of MSSs, especially the ISO 9001 and ISO 14001 standards, has attracted the interest of several researchers in recent years with a view to: (i) ascertaining the present pattern of diffusion; and (ii) forecasting what the future of these standards might be (Franceschini et al., 2004, 2006, 2010; Marimon et al., 2006, 2009; Casadesús et al., 2008). These studies have established that different countries are at different stages in the evolution of diffusion of these standards. For example, it would seem that countries that are more experienced in implementing MSSs (such as many European countries) will reach saturation of ISO 9001 and ISO 14001 in a relatively short time (even though the absolute rate of registrations appears to be decreasing), whereas some other countries, in which certification under quality standards has a shorter history, are at a much earlier stage in the diffusion process. However, all of these studies have analysed the phenomenon from a 'macro' perspective across whole countries, with little attention having been paid (at least thus far) to specific industry 
sectors. Moreover, little research attention has been paid to other QMS standards (apart from ISO standards) that organisations might have implemented.

In view of these gaps in the literature, the aim of the present study is to compare the diffusion of two QMSs within the Spanish tourism sector. The two QMSs for examination are ISO 9001 (which is a well-known and widely diffused generic international standard) and 'Q' (which is a specific certification standard developed for tourism in Spain). The objectives are threefold: (i) to ascertain whether the two standards follow the same diffusion pattern; (ii) to identify similarities and dissimilarities between the two QMSs; and (iii) to identify the main drivers for the diffusion of the standards.

Tourism is chosen as the industry sector of interest for two reasons. First, tourism is emerging as a vital driver of economic growth in both developed countries and developing countries (WTO, 2010). Secondly, some countries have developed their own specific tourism QMSs, and it is therefore interesting to compare these specific standards with the well-known and well-established international standards (such as ISO 9001).

The remainder of the paper is structured as follows. The next section reviews the literature on diffusion models, with particular reference to the diffusion of QMSs. The methodology of the empirical study is then presented. The results of the study are then presented. The paper concludes with a summary of the main findings and implications.

\section{Literature review}

\subsection{Diffusion of QMS standards}

Most models of the diffusion of QMS standards have likened the process to the diffusion of technological and organisational innovations in society. According to Rogers (1995, p. 35), the diffusion of an innovation is a "process by which an innovation is communicated through certain channels over time among the members of a social system." Numerous studies have examined various aspects of such innovation diffusion. Mahajan et al. $(1990,1995)$ investigated 
how an innovation spreads through an economy, and Gurbaxani (1990) reported that new product innovations in many industries follow a so-called 'S-curve' (that is, a relatively slow rate of uptake at the beginning, followed by a rapid acceleration, and then a tapering in the rate of adoption as saturation is approached). Other studies to have supported this view with regard to both organisational and technological innovations include Teece (1980), Stoneman (1995), MacVaugh and Schiavone (2010), and Kumar et al. (2009). However, it would seem that the actual speed of diffusion is highly industry-specific and can be fairly slow in the case of new technologies (Loch and Huberman, 1999; Geroski, 2000).

With regard to the worldwide diffusion of the ISO 9001 and ISO 14001 standards, which is the specific interest of the present study, several authors have sought to identify the key factors affecting the process. Corbett and Kirsch $(2001,2004)$ and Vastag (2003) found that the rate of diffusion of the standards depended on two main factors: (i) the geographical location; and (ii) a history of having implemented previous standards (for example, a greater number of ISO 9001 certifications in a country appears to have been an enabler for the subsequent diffusion of ISO 14001 in the same country). According to Delmas (2002), the institutional environment (i.e. governments and governmental organisations) promotes the pattern of diffusion of ISO 14001 in both Europe and in the USA, although the impact of diffusion in each geographic area was found to differ - being favourable in Europe but unfavourable in the USA. Another factor affecting the diffusion, according to Prakash and Potoski (2007), is direct foreign investment (e.g., companies with ISO 14001 certifications investing in host companies in other countries. Corbett (2006) suggested that supply chains play a role in the global diffusion of management practices. Albuquerque et al. (2007) found that the diffusion of ISO 9001 is driven primarily by geography and bilateral trade relations, whereas the diffusion of ISO 14001 is driven primarily by geography and cultural affinity. Other studies have concluded that diffusion is explained by the level of trading relations among countries and the number of certifications of 
other standards includes those of Saraiva and Duarte (2003), Franceschini et al. (2004), and Sampaio et al. (2009).

Organisations adopt management systems because they enable them to become more competitive. The benefits and the drawbacks of ISO 9001 and ISO 14001 have been analysed from both an academic and an organisational standpoint (e.g., Davies and Webber, 1998, Del Brio et al., 2001, Tan, 2005, Gonzalez-Benito and Gonzalez-Benito, 2005 and 2008, Gimenez et al., 2006).

The diffusion of both standards has also been studied in depth and comparative analyses have been undertaken of their patterns of diffusion. In most cases, the analyses have been cross-national (e.g., Franchescini et al., 2004, Marimon et al., 2006 and 2009, Casadesus et al., 2008).

Another contribution to the literature on standards diffusion has been the classification of countries according to the growth rate of certifications (Marimon et al., 2006, 2009; Casadesus et al., 2008). Having confirmed that ISO 9001 and ISO 14001 diffusion follows a logistic (or S-curve), these authors have classified various countries in terms of the phases of the S-curve as being: (i) 'expansionist' (where the ISO 9001 and ISO 14001 certification intensity rates are growing); (ii) 'mature' (where the ISO 14001 intensity rate is increasing, but the ISO 9001 intensity rate is decreasing); and (iii) 'retrocessive' (where the intensity rate of certifications in both ISO 9001 and ISO 14001 has begun to decrease).

It should be remembered that this S-curve pattern suggests an evolution from the first stages, characterised by a low number of certifications, to the last stage, marked by saturation, i.e. when the maximum forecasted number of certifications is reached. In other words, the saturation point represents an estimate of the potential adopters of the standard concerned in terms of the number of organisations that will eventually implement it.

More recently, similar results were obtained by Franceschini et al. (2010), who clustered the European countries based on ISO 9001 certifications, at a macro-level, into three different 
groups: (i) 'constant growth area' (the number of certifications is currently growing); (ii) 'saturation area' (the number of certifications has settled around a saturation value); and (iii) 'decline area' (the number of certifications has decreased). In these studies the majority of countries are in the first two groups, i.e. there is potential for increasing the certification growth rate in the first group, and in the second, the number of certifications in each country has reached the highest level of growth and cannot continue growing (i.e. has reached saturation point), depending on each country's experience in implementing and managing these international standards.

The data used in these various studies have usually been aggregated by country or other geographical area, but very few have analysed the diffusion of standards in terms of industry sectors. It was only recently that Llach et al. (2011) classified the diffusion of standards by activity sector, which provides new clues to understanding the diffusion phenomenon. The present study addresses this gap in the literature by examining the diffusion of quality standards in the Spanish tourism sector.

\subsection{QMS standards in tourism}

Tourism accounts for $70 \%$ of the overall contribution of services to global gross domestic product (GDP) (WTO, 2010). Spain is the third most important tourist destination in the world, receiving 55.70 million travellers in 2010, employing 2.49 million persons in the sector and with tourism representing 10\% of Gross Domestic Product (IET, 2011). Moreover, forecasts indicate that this sector will continue to grow globally in the coming years, despite the global economic downturn (WTO, 2010).

The implementation of quality systems in the tourism sector is important in Spain if the country is to maintain its competitive position despite the challenges that are arising as a result of the worldwide changes occurring in destinations and consumer tastes (Tribe, 1999). These changes include increasing environmental awareness and declining loyalty to traditional tourist destinations as the quality of new destinations improves (O'Connor and Frew, 2002; Kim et al., 
2007). The hardening of the competitive environment requires new strategies by tourism providers (Testa and Sipe, 2006; Briggs et al., 2007; Pereira-Moliner et al., 2010), including the adoption of recognized quality standards (Nield and Kozak, 1999; Susskind et al., 2007).

ISO standards (in general) have been widely accepted in Spain, as evidenced by the fact that Spain ranks third in the world (behind only China and Italy) in the number of ISO 9001 certifications (AENOR, 2011). It would have been reasonable to assume that the Spanish tourist industry would follow this trend; however, it appears that this has not been the case. In fact, by 2009 only 282 hotels and restaurants in Spain had been certified in accordance with the ISO 9001 standard, compared with a total number of 59,576 certificates in Spain (Forum Calidad, 2010). This means that only $0.005 \%$ of the certificates were awarded to hotels and restaurants. This low penetration of ISO 9001 was studied by Camison and Yepes (1994), who found that hotels considered that the main barriers to adoption were the costs of implementation and the lack of staff training (Camison et al., 2006).

Given this situation and the need to provide tourism businesses with a tool for quality management adapted to their needs, the Spanish government launched the Spanish Touristic Quality System Project (STQS) in 1996 with two main objectives (Alonso-Almeida et al., 2009):

* $\quad$ equipping Spanish tourism companies with a common methodology to establish a management system and thus improve quality of service to a standard that will enable Spanish tourism providers to maintain and improve their competitive position; and

* supporting brand recognition of the distinctive Spanish 'Q' quality trademark as an indication of superior quality.

The Spanish 'Q' standard covers four main aspects: (i) facilities; (ii) the final service delivered to the client; (iii) organisational processes of client services; and (iv) functions and management tools for customer satisfaction. As such, the 'Q' standard is a self-regulated standardisation system that establishes quality standards compatible with the ISO 9000 and ISO 
14000 series of standards (Alonso-Almeida et al., 2009). In other words, the 'Q' standard is complementary to both international standards. The main characteristics of the 'Q' standard and the ISO standards are presented in Table 1.

\section{"Take in Table 1"}

Table 1. Main characteristics of international standards and 'Q' standard

The agency responsible for the development, application, compliance, and dissemination of the 'Q' standard is the Institute for Spanish Tourism Quality (ICTE). The ICTE, which was established in 2000, has published twenty different quality standards for various aspects of the tourism industry—such as travel agencies, tourist information, convention bureaux, ski and mountain resorts, rural accommodation, and restaurants. Of these twenty, six standards have been transformed from ICTE standards into UNE Rules (Una Norma Española = 'One Spanish Norm'), which gives greater recognition in the national territory (ICTE, 2010).

The growth of 'Q' certifications from 2000 to 2009 is shown in Figure 1. The graph shows the total number of certifications per year, as well as the certifications among sub-sectors with large numbers of registrations. It is apparent that, from 2000 to 2003, the growth was slow; however, since 2004 there has been a considerable increase. This increase can be attributed to the support of the administration, national and international campaigns, training programs, and, since 2007, the creation of a directory of certified firms and an information manual on certification (Alonso-Almeida et al., 2009). Indeed, hotels and restaurants with Q certification represent more than $50 \%$ of the tourist companies certified (ICTE, 2010).

\section{"Take in Figure 1"}

Figure 1. Number of 'Q' certifications (Spanish tourism sector) (2000-09) 
Taking into account the known (S-shaped) diffusion pattern of ISO 9001 (as described above) and the similarities between this international standard and the Spanish 'Q' standard, the hypothesis to be tested in this paper can be stated as follows:

* Diffusion of the 'Q' standard follows the same pattern as that of the ISO 9001 standard within the specific sector of 'hotels and restaurants.'

The methodology applied to test this hypothesis is presented below.

\section{Methodology}

\subsection{Data sources}

Data on the diffusion of ISO 9001 were obtained from ISO annual reports ("ISO Survey") and from annual reports provided by Foum Calidad (with regard to diffusion in Spain). Data on the 'Q' standard data were obtained from ICTE databases.

The ISO data have two main drawbacks. First, ISO does not itself perform certification to its standards, does not issue certificates, and does not verify certifications performed independently of ISO by other organisations. Secondly, not all data sources respond to the request for data on sector aggregation, with the result that the overall figures for the 39 designated sectors should be taken as rough indicators only. Although this problem is less likely to be significant when considering only one sector (as contrasted with comparisons among the 39 sectors surveyed), these reservations should be borne in mind when considering the data for the evolution of ISO 9001 certifications in the 'hotels and restaurants' sector (as shown in Table 2). The table includes both the worldwide data and the data for Spain.

\section{"Take in Table 2"}

Table 2. Number of ISO 9001 certifications for 'hotels and restaurants' sector 1998-2008 (global and Spain) 
The data for the 'Q' standard are shown in Table 3. In this table, an aggregation has been made to make data more comparable to ISO 9001. The table shows only those sub-sectors that are equivalent to 'Hotels and restaurant.'

"Take in Table 3"

Table 3. Number of ' $Q$ ' certificates by sub-sectors and aggregated for sub-sectors 2, 3, 5, 6, 11, and 15 (Spain, 1998-2009)

\subsection{Data analysis}

The analysis consisted of three main phases. First, the data were analysed to ascertain whether the evolution of the numbers of certifications in Spain of the ISO 9001 standard and the Spanish 'Q' standard fit the logistic curve. Previous studies that have analysed data aggregated by country (Franceschini et al., 2004, 2010; Marimon et al., 2006, 2009; Casadesus et al., 2008) have established that the logistic curve provides a good fit with the diffusion of ISO 9001 and ISO 14001 (although there have been no previous studies dealing with aggregated data by sector of activity).

Secondly, the same analysis was applied to the diffusion of ISO 9001 for the 'hotels and restaurants' sector and to the diffusion of 'Q' certificates.

In undertaking these analyses, the logistic curve is expressed by the following equation:

$$
N=\frac{N_{0} K}{\left(K-N_{0}\right) e^{-r_{0} t}+N_{0}}
$$

in which:

$\mathrm{N}$ represents the number of individuals (over time);

$\mathrm{N}_{0}$ represents the number of individuals at the starting point;

$\mathrm{K}$ is the saturation level; 
$\mathrm{r}_{0}$ is the initial growth rate; and

$\mathrm{t}$ is independent variable (time).

The kernel of the model is the differential equation:

$\frac{d N}{d t}=r N$

The increase of a population is proportional to its size $(\mathrm{N})$, where rate $\mathrm{r}$ (whose units are the inverse of time) represents the proportional increase of the population $\mathrm{N}$ in one unit of time. This rate varies according to the expression:

$r=r_{0}\left(1-\frac{N}{K}\right)$

Thirdly, the analysis focused on six case studies of hotels and restaurants. The qualitative data from these case studies were compared with the quantitative data obtained from the preceding empirical analyses. The aim was to identify qualitative explanations for the quantitative findings.

\section{Analysis and results}

\subsection{Diffusion of ISO 9001 and ISO 14001 worldwide}

The diffusion patterns of ISO 9001 and ISO 14001 certifications are presented in Figure 2. It can be seen that the logistic curve fitted well to the aggregated number of worldwide certificates under both standards. This finding is in accordance with previous studies (Marimon et al., 2006, 2009; Casadesus et al., 2008). Regressions are presented in the table associated with the graphs, which includes a scaling of the curves in terms of their respective percentage values of saturation in order to allow for comparisons between the evolutions of both standards.

It should be noted that the worldwide ISO 9001 certifications (close to one million in 2008) were, in absolute numbers, five times more numerous than ISO 14001 certifications. 
However, in percentage terms, the two standards were at a similar level. In late 2008, ISO 9001 registrations were at $74.5 \%$ of saturation, whereas ISO 14001 registrations were at $72.9 \%$ of saturation. According to these patterns, ISO 9001 certifications will reach $95 \%$ saturation in 2014, whereas ISO 14001 certifications will reach saturation one year earlier, in 2013. In other words, although ISO 14001 was published nine years later than ISO 9001, the relative levels of the two standards were similar in 2008 due to ISO14001 growing at a faster rate.

\section{"Take in Figure 2"}

Figure 2. Logistic curves and forecast of certifications for ISO 9001 and ISO 14001 worldwide

\subsection{Logistic curve of ISO 9001 certifications for 'hotels and restaurants' sector}

Figure 3 shows the application of the S-curve to the data on ISO 9001 certifications in the worldwide 'hotels and restaurants' sector. In this analysis, data from 1999 and 2008 were not included because they were clearly aberrant (see white plots in Figure 3). As previously noted, data collected by ISO include some erroneous numbers, which is acknowledged by the organisation itself. Certainly, in any given year, a discrepancy between the annual total certifications from the 39 sectors of activity and the total certifications from the national totals is found. It is observed that the sum of the national totals is always greater than the sum of the totals by sector. This gap was especially significant in 2008 , when the totals of the certifications by sectors represented only approximately $50 \%$ of the total of the certifications in terms of national totals (ISO, 2009). These aberrant numbers were therefore ignored in the present analyses.

Figure 3 and its attached table show that the model fitted well, with an $\mathrm{R}^{2}=0.984$. The model was robust, and the three parameters were significant with a confidence level of $95 \%$ $(p<0.05)$. It can be anticipated that the 'hotels and restaurants' sector certificates will reach $95 \%$ saturation in 2013. 
"Take in Figure 3"

Figure 3.- Logistic curve and forecast of ISO 9001 certifications for "Hotels and restaurants" sector worldwide

An additional analysis was performed on the data for ISO 9001 certifications of hotels and restaurants in Spain alone (see Figure 5). The number of certifications for 2009 was discarded from this analysis because it was extremely small compared with that of the previous year (see asterisk plot in Figure 5). The explanation for this aberrant number is the same as for the worldwide data noted above. The regression of the logistic curve fitted well $\left(\mathrm{R}^{2}=0.993\right)$. All three parameters were significant (with a confidence level of 95\%). The saturation level of 546 certifications correponds with the level for 2008. However, although the model provides a good explanation of the evolution of the certifications, it does not appear to be valid for forecasting the future. Indeed, the value for 2009 (282) does not follow the trend; it would seem that this standard is becoming less popular in the 'hotel and restaurant' sector.

In summary, although the application of the ISO 9001 standard in the hotels and restaurants sector is expanding on a worldwide scale, the standard appears to have reached saturation point in Spain. Arguably, the certification growth rate appears to have begun to decline, as pointed out by previous studies, such as Marimon et al. (2006 and 2009) and Casadesus et al. (2008). The question that arises now is: what is the reason for this divergence of behaviour? Why does the standard still seem to be in the expansionist phase on a worldwide scale, while in Spain saturation point has been reached?

\subsection{Logistic curve of ' $Q$ ' certifications}

As previously noted, the data used in the analysis of ' $Q$ ' certifications were drawn from certain subsectors (see Table 3) that were aggregated to facilitate comparisons with the data provided by the ISO regarding 'economic activity code 30' (that is, 'hotels and restaurants'). 
As shown in Figure 4, the logistic curve again fitted the data well $\left(\mathrm{R}^{2}=0.998\right)$. The three parameters of the regression were robust with a confidence level of $95 \%(p<0.05)$. The curve suggests that the standard will reach $95 \%$ saturation in 2018 ; that is, five years after the ISO 9001 worldwide for this sector.

"Take in Figure 4"

Figure 4.- Logistic curve and forecast of Spanish Q certifications

\subsection{Comparison of diffusion of ISO 9001 and Spanish ' $Q$ ' standard}

Figure 5 compares the evolution of ISO 9001 certifications in the 'hotels and restaurants' sector in Spain with the evolution of certifications under the Spanish 'Q' standard. It is apparent that there has been considerable divergence in the graphs in the past two years. Whereas the number of certifications under the 'Q' standard is growing, the number of certifications under ISO 9001 in this sector in Spain is decreasing. These findings are in accordance with the ISO 9001 standard having reached saturation in this sector in Spain in 2008, followed by a smaller number of certifications of this standard in 2009 (as shown in Figure 5). In addition, it would seem that there is evidence of a phenomenon of 'de-certification' in 2009 as hotels and restaurants in Spain have not renewed their ISO 9001 certificate. However, the data for the latter phenomenon are not conclusive because only one year has passed since the saturation point. It will be necessary to wait and see what happens in the future to confirm this trend.

\section{"Take in Figure 5"}

Figure 5. Comparison between diffusion models of "hotels and restaurants" sector of ISO 9001 and Spanish Q standard 
It is thus apparent that the two standards are at different stages on the logistic curve. Whereas ISO 9001 ('hotels and restaurants' sector in Spain) is saturated, the 'Q' standard is still growing; indeed, it would seem that the latter will not reach saturation until 2019. In seeking to explain why saturation has occurred so early in the case of ISO 9001 and why the 'Q' standard continues to grow, qualitative data on the diffusion of the two standards in Spanish tourism were obtained from a selection of case studies.

\section{Case studies}

Case studies have frequently been used in the literature to explain various aspects of the dissemination, adoption, implementation, and integration of quality standards (Fresner and Engelhardt, 2004; Labodová, 2004; Zutshi and Sohal, 2005; Ghisellini and Thurston, 2005; Sumiani et al. 2007; Rodriguez-Antón et al., 2008; Karapetrovic and Casadesus, 2009; Casadesus et al., 2010). In the present study, extensive interviews were conducted with managers of hotels and restaurants in Spain with a view to ascertaining the main drivers of implementation of the two standards under investigation. Six case studies of the implementation of ISO 9001 and 'Q' in Spanish hotels and restaurants are presented.

\subsection{Case 1: ISO 9001 in hotel chain}

The first case study concerns a French-based international hotel chain (more than 800 hotels worldwide) that has 42 properties in major Spanish cities. All of the chain's hotels are certified in accordance with the ISO 9001 standard. The hotel chain targets business clients with a business strategy of offering good quality at an affordable price. When asked why the organisation had chosen this quality standard, the CEO of a hotel located in Madrid replied:

"The chain's policy is to certify to this standard all hotels that are incorporated into the brand. The purpose of this strategy is to enable supply of the same quality service in all parts of the world." 
To achieve this objective, a team from the chain's central quality department works with local employees to implement the ISO 9001 standard in every new hotel. This team provides training and tools to ensure successful implementation and operation.

It would seem that the ISO 9001 standard is used by this chain because the standard is international and is recognised as an indication of quality by its clients from various countries. When asked whether the company intended to incorporate any other standards, the CEO replied: "The hotel chain has begun to certify its hotels with ISO 14001; indeed, it has already certified more than 200 worldwide. This hotel will be certified under the ISO 14001 standard next year ... Senior corporate managers in the chain make such strategic decisions; individual hotels have no choice."

\subsection{Case 2: ISO 9001 in independent hotel}

The second case study concerns a luxury hotel in central Madrid, which focuses on a client profile of high-level businesspersons. The hotel has 180 rooms and suites and 150 employees. When asked why the hotel had selected the ISO 9001 standard as its QMS, the CEO said: "The board favoured an international standard because $70 \%$ of our customers are foreigners and this standard is familiar to them ... [Moreover] given that more than 40 people work in the reception area alone, having written procedures has been very useful. It enables quick learning and inclusion of our new and temporary employees."

When asked about the possibility of incorporating new standards, he said:

"We are interested in implementing standards to manage environmental issues. We are also looking to achieve savings in our electrical and water consumption, among others. We would therefore like to be certified under the ISO 14001 standard in future ... [However] next year we will also incorporate the 'Q' standard because we believe that it is complementary to ISO 9001.” 


\subsection{Case 3: ' $Q$ ' in hotel chain}

The third case concerns one of the largest Spanish-based hotel chains, which has a presence in 15 countries around the world. This chain specialises in luxury leisure tourism. The chain has opted to implement the Spanish 'Q' quality standard and currently has 10 certified hotels. According to the operations manager:

"We wish to assure current and potential customers that our hotels follow processes that ensure the provision of superior quality in all categories of service. Having an industry-specific QMS has enabled the design of appropriate procedures in all departments."

With regard to environmental certificates, the operations manager observed:

"The chain implements specialised certificates — such as the Green Globe certificate, the Sustainable Tourism Program of Costa Rica, or other national certificates of the countries in which the hotels are located ... Our strategy for the coming years is to continue implementing country-specific certificates in both quality assurance and in environmental management."

With regard to the ISO 9001 standard, the manager said:

"We want to certify our 50 hotels in Spain with the 'Q' standard ... The ISO standard is too generic for our business. Before deciding on the 'Q', we conducted a pilot program in a hotel with the ISO 9001, but it did not work."

\subsection{Case 4: ' $Q$ ' in boutique hotel}

The fourth case concerns a small independent hotel with 15 rooms located in a city in eastern Spain. The customers of this hotel are drawn almost equally from leisure and business travellers. The hotel has been certified in accordance with the 'Q' standard since 2008. The hotel manager explained the certification in the following terms: 
"From the beginning, management decided to implement the 'Q' standard because the regional government supported this standard, the required investment was reasonable, and the prospective benefits (both external and internal) appeared to be significant ... We are pleased with the results and we do not plan, at least for now, to implement other management standards. The current QMS has some environmental practices that are sufficient for a business of our size."

\subsection{Case 5: ISO 9001 in restaurant}

The fifth case study concerns a chain of seven prestigious restaurants in southern Spain. By 2009, three of the restaurants had been certified in accordance with the ISO 9001 standard. The general manager explained the chain's adoption of the ISO 9001 standard in the following terms:

"Most of our clients are executives of Spanish or foreign companies who look for a good meal to celebrate success in their businesses. Other customers are foreigners with high purchasing power who come to enjoy quality cuisine while on their holidays. We wanted this certification to improve the quality of our service, and thus improve customer satisfaction. In addition, we wanted to enhance our image in both traditional channels and the Internet. This international certification improves our image because the ISO standards are internationally popular ... We have also begun to implement the requirements of the ISO 14001 certificate, although we have yet to have a restaurant certified with this standard."

With regard to the 'Q' standard, he said:

"We are not yet prepared to adhere to a standard that involves remodelling of all our business processes. We prefer starting with small steps, although we do not rule out implementing the 'Q' in the future." 


\subsection{Case 6: $Q$ in restaurants}

In late 2009 , there were only 196 restaurants certified in accordance with the 'Q' standard. According to these restaurants' managers, the majority selected this standard because:

“'Q' has strong institutional support and is easy to implement because it is adapted to our business.

The cost of certification and maintenance is not very high. We think that it provides a high added value to the product that we sell.

We believe it is sufficient, at least for the moment, for the management of service quality and environmental issues."

It should be noted that most restaurants are small companies and this standard, which is specifically designed for restaurants, has provided the possibility of implementing a standard at low cost without requiring many specialised resources.

\subsection{Dicussion of Case Studies}

Castka and Balzanova (2008) stated that certain factors such as the structure and ownership of the organisation concerned influence management standard adoption strategies. Some authors (Rodríguez-Antón and Alonso-Almeida, 2008; Molina-Azorin, et al., 2009; Alonso-Almeida and Rodriguez-Antón, 2011) found that in the hotel industry, management system adoption could be influenced, mainly, by two factors: (i) whether a hotel operates independently or as part of a hotel chain; and (ii) the type of customer it attracts.

With regard to ownership, our findings suggested that when a hotel belongs to a chain, the decision about which QMS to implement is taken by the chain's head office, and the hotel merely impelments this decision and operates accordingly. Our findings also suggest that the nationality of the head office could play a key role in the choice of QMS. The representative may prefer a single internationally well-known QMS for the whole chain managed from the owning company's head office. 
On the one hand, then, when the hotel chain is foreign-owned, the ' $Q$ ' standard may not be the best choice, since it is only recognised inside Spain. On the other hand, other hotel chains operating in Spain could choose a dual strategy of implementing the 'Q' standard in Spain and another QMS in their overseas hotels. Indeed, this is the strategy followed by a famous American fast-food restaurant chain, which has certified all its restaurants in Spain with the ' $Q$ ' standard and has implemented the ISO 9001 in other countries.

In addition, these findings also highlight the importance of market scope as a driver in the selection of a QMS standard: the selection of a QMS may well be influenced by the market scope of the company. Nevertheless this finding should be taken with caution, as it is only inferred from our case study. More specific research is needed to underpin it.

Regarding the influence that customer type can have on certification decisions, our case studies suggested that when the main type of customer is foreign, tourist companies prefer a well-known international standard. Likewise, given the large-scale promotion of the ' $Q$ ' mark by ICTE, when the main type of customer is Spanish, companies are more likely to implement this standard. This finding also needs more research, however, in order to validate it.

Another finding has suggested that internal motivation may be a reason for choosing a particular QMS standard. Previous research has shown that hotels in Spain implement a QMS mainly as a result of internal motivation (Alonso-Almeida et al., 2010; Alonso-Almeida and Rodriguez-Anton, 2011), and a specific tourist industry quality standard that fits with the market characteristics of theses hotels could help to align business objectives and business processes.

Finally, other motivations for choosing the 'Q' standard were institutional support and reasonable costs. This finding is in line with the pioneering study conducted by Camison and Yepes (1994) who found that the cost of ISO 9001 implementation and maintenance acted as a barrier which could explain the low rate of penetration of this standard. Futhermore, institutional support from ICTE and the public administration will probably continue, and the diffusion of the 'Q' standard will therefore almost certainly continue to grow in the near future. 


\section{Conclusions}

The aim of this study was to compare the diffusion of two quality management systems (QMSs) within the the Spanish tourism sector. The two QMSs for examination were: (i) the ISO 9001 for 'hotels and restaurants'; and (ii) 'Q', which is the certification standard for tourism in Spain. The objectives of the study were threefold: (i) to ascertain whether the two standards follow the same diffusion pattern; (ii) to identify similarities and dissimilarities between the two QMSs; and (iii) to identify the main drivers for the diffusion of the standards. After analysing data covering more than a decade of certifications, the conclusions of the study can be stated as follows.

First, the diffusion pattern of certifications under both standards have been shown to follow a logistic curve. The fit of data for both standards to this curve was very high, with a better than $98 \%$ fit in both cases.

Secondly, although ISO 9001 certifications worldwide will reach 95\% saturation in 2014, ISO 9001 certifications for the 'hotels and restaurants' sector in Spain had already reached saturation in 2008. This situation reflects the fact that the growth rate for the hotels and restaurants' sector was greater than that of global certifications of ISO 9001. With regard to the 'Q' standard, certification saturation is expected to be reached in 2019.

Thirdly, two main differences in the growth rates of the two standards have been found. First, ISO 9001 sector certifications have grown faster than the 'Q' certifications over the same period of time. This difference could be due to the international scope of the ISO 9001 standard. Secondly, the stage of diffusion of the two standards differs. According to the stages described by Marimon et al. (2009), ISO 9001 sector certifications have almost reached saturation point and could thus be classified in the 'retrocessive stage,' whereas 'Q' standard certifications are still growing, which places them in the 'expansionist stage.' These data should, however, be taken cautiously and the phenomenon needs to be analysed further in the coming years. 
Fourthly, both the quantitative data from the official sources and the qualitative data from the case studies have provided evidence of a trend in the 'hotels and restaurants' sector in Spain. It would seem that, in the coming years, there is likely to be a continuation of the trend to favour industry-specific standards at the expense of the generic ISO 9001 standard, which would seem to be in decline, meaning that the number of new certifications will not grow as fast as in the past. However, this trend within this specific sector in Spain is not a worldwide trend; indeed, it would seem that the 'Q' standard is in the 'maturity phase' and still has a few years to go before reaching saturation.

The main drivers identified for the choice of the 'Q' standard, according to the evidence detected in the business cases analysed, were: (i) institutional support; (ii) ease of implementation due to familiarity with the implementation procedures; and (iii) the reasonable cost. The further illustration of these aspects will be a priority line for future research.

As previous research has pointed out (Rodríguez-Antón and Alonso-Almeida, 2008; Molina-Azorin, et al., 2009; Alonso-Almeida et al., 2010; Alonso-Almeida and Rodriguez-Antón, 2011), this study also provides evidence concerning the relevance of ownership, type of customers, and motivations as factors when choosing a QMS. Futhermore, there is evidence to indicate that other factors that could play a critical role in the future diffusion of the standard management systems in the tourist industry are the nationality of hotel chains' head offices and the market scope of the establishments concerned.

These drivers seem to differ from the reasons identified in the literature for the dissemination of international standards in the industrial sector, which included: (i) pressure from customers (Hardjono et al., 1997; Magd and Curry, 2003); and (ii) competition (Taylor, 1995; Hardjono et al., 1997, Leung et al. 1999). The scant evidence found concerning the motivation for implementing a quality system in the hospitality industry showed that the main reasons are internal, such as the need to improve inter-departmental coordination, to establish correct working procedures (Harrington and Akehurst, 2000; Alonso-Almeida et. al, 2010) and 
to eliminate variability in the provision of customer services (Susskind et al., 2007). These reasons suggested that industry-specific standards seem more appropriate for service providers in the hospitality and tourism sector. Indeed, even those that have opted for certification under the ISO 9001 standard in the present study did not rule out adopting the industry-specific 'Q' certification in future as a complementary system.

The results have some interesting implications for managers and public policy-makers. For managers of service companies in the tourism sector, it would seem prudent, when selecting a QMS, to take into account the potential benefits of sector-specific standards as compared with other (more generic) standards. This recommendation does not mean chosing one or the other, as both are complementary and having both implemented could mean gaining competitive advantage. For public policy-makers, the implication of the present findings is that they should support initiatives that encourage the development of standards and management tools that are specific to the particular needs of companies in specific sectors, regardless of size with the aim to make them competitive, as is the case of the 'Q' standard that has governmental support.

In summary, the main contribution of this paper has been to explore the spread of QMSs in a specific sector. In doing so, the study has made an original contribution because all existing studies of the diffusion of quality standards have focused on the geographical spread, while the diffusion in specific sectors is very scarce. It is acknowledged that the results might not be readily generalisable to other sectors and other countries, but both standards seem to be complementary which means representing a source of competitive advantage. Nevertheless, the methodology would seem to be valid and relatively easy to replicate in other settings.

The main limitation of this study is the model applied as it does not reflect the factors that afect the diffusion, such as the global crisis or another local causes. This point in addition to analysing the motivations of implementing one systems or another will base the future research. 


\section{Acknowledgements}

This article was written as part of a research project entitled "Customers' satisfaction

improvement in Spanish organisations through standardisation" (ECO2009-12754-CO2-01)

financed by the Ministry of Science and Innovation within the aid program for $\mathrm{R}+\mathrm{D}$ projects. 


\section{References}

AENOR (2011). Summary about last worldwide ISO report. Press Note 3270 jan. Available in www.aenor.es. Accessed June, 22, 2011.

Albuquerque, P., Bronnenberg, B., Corbett, C. (2007), “A spatiotemporal analysis of the global diffusion of ISO 9000 and ISO 14000 certification”, Management Science, Vol. 53, No. 3, pp. 451-68.

Alonso-Almeida, M.M., Rodriguez-Antón, J.M. (2011). "Organizational behavior and strategies in the adoption of certified management systems. an analysis of the Spanish hotel industry". Journal of Cleaner Production, Vol. 19, nº 13, pp.1455-1463.

Alonso-Almeida, M.M.; Rodríguez-Antón, J.M., Rubio-Andrada, L. (2010). "Reasons for implementing certified quality systems and impact on performance: an analysis of the hotel industry”, The Service Industries Journal. DOI: 10.1080/02642069.2010.545886.

Alonso-Almeida, M., Casadesus, M., Marimon, F. (2009), "The Diffusion of Standardised Quality Management in Hotel Industry in Spain”, POMS 20th Annual Conference, Orlando, Florida U.S.A., May 1 to May 4, 2009.

Briggs, S., Sutherlanda, J., Drummond S. (2007), "Are hotels serving quality? An exploratory study of service quality in the Scottish hotel sector", Tourism Management, Vol. 28, pp. $1006-1019$.

Camison, C., Cruz, S., González, T. (2006). Gestión de la calidad. Conceptos, enfoques, modelos y sistemas. Pearson-Prentice Madrid.

Camisón, C. and Yepes, V. (1994). "Normas ISO 9000 y Gestión de Calidad Total en la empresa turística". I Congreso de Calidad de la Comunidad Valenciana, Valencia november 2004.

Casadesus, M., Heras, I. (2005), “El Boom de la calidad en las empresas españolas”, Universia Business Review, pp. 90-101. 
Casadesús, M., Marimon, F., Heras, I. (2008), "Countries behavior regarding to the diffusion of ISO 14000 standards”, Journal of Cleaner Production, Vol. 16, No. 16, pp. 1741-1754.

Casadesús, M., Marimon, F., Alonso-Almeida, M. (2010), “The Future of Standardised Quality Management in Tourism: Evidence from the Spanish Tourist Sector" The Service Industries Journal, Vol., 30, No. 14, pp. 2457-2474.

Castka, P., Balzarova, M. A., 2008. The impact of ISO 9000 and ISO 14000 on standardisation of social responsibility-an inside perspective. International Journal of Production Economics. $113,74-87$.

Corbett, C. Kirsch, D. (2001), "International diffusion of ISO 14000 certification", Production and Operations Management, Vol. 10, No. 3, pp. 327-342.

Corbett, C. Kirsch, D. (2004), "Response to "Revisiting ISO 14000 Diffusion: A New "Look" at the Drivers of Certification", Production and Operations Management, Vol., 13, No. 3, pp. 268-271.

Corbett, C. (2006), "Global Diffusion of ISO 9000 Certification Through Supply Chains", Manufacturing \& Service Operations Management, Vol.8, No. 4, pp. 330-350

Delmas, M. (2002), "The diffusion of environmental management standards in Europe and in the United States: An institutional perspective”, Policy Sciences, Vol. 35, pp. 91-119.

Forum Calidad (2001), “Certificación en España según normas UNE-EN- ISO 9000 y ISO 14000 Sexto informe de Forum Calidad", Forum Calidad Vol. 120, pp. 8-14.

Forum Calidad (2002), “Certificación en España según normas UNE-EN- ISO 9000 y ISO 14000 Septimo informe de Forum Calidad”, Forum Calidad, Vol. 130, pp. 9-16.

Forum Calidad (2003), “Certificación en España según normas UNE-EN- ISO 9000 y ISO 14000 Octavo informe de Forum Calidad”, Forum Calidad, Vol. 140, pp. 7-14.

Forum Calidad (2005), “Certificación en España según normas UNE-EN- ISO 9000 y ISO 14000 Decimo informe de Forum Calidad", Forum Calidad, Vol. 160, pp. 22-30. 
Forum Calidad (2006), "Certificación en España según normas UNE-EN- ISO 9000 y ISO 14000 Undécimo informe de Forum Calidad”, Forum Calidad, Vol. 170, pp. 20-27.

Forum Calidad (2007), “Certificación en España según normas UNE-EN- ISO 9000 y ISO 14000 Duodécimo informe de Forum Calidad”, Forum Calidad, Vol. 180, pp. 22-28.

Forum Calidad (2008), “Certificación en España según normas UNE-EN- ISO 9000 y ISO 14000 Decimotercer informe de Forum Calidad”, Forum Calidad, Vol. 190, pp. 22-28.

Forum Calidad (2009), “Certificación en España según normas UNE-EN- ISO 9000 y ISO 14000 Decimocuarto informe de Forum Calidad”, Forum Calidad, Vol. 200, pp. 22-27.

Forum Calidad (2010), “Certificación en España según normas UNE-EN- ISO 9000 y ISO 14000 Decimoquinto informe de Forum Calidad”, Forum Calidad, Vol. 210, pp. 22-27

Franceschini, F., Galetto, M., Gianni, G. (2004), "A new forecasting model for the diffusion of ISO 9000 standard certifications in European countries", International Journal of Quality \& Reliability Management, Vol. 21, No. 1, pp. 32-50.

Franceschini, F., Galetto, M., Cecconi, P. (2006), “A Worldwide análisis of ISO 9000 standard diffusion, Considerations and future development", Benchmarking: An International Journal, Vol. 13, No. 4, pp. 523-541

Franceschini, F., Galetto, M., Masiano, D., Mastrogiacomo, L. (2010), “Clustering of European countries based on ISO 9000 certification diffusion", International Journal of Quality $\&$ Reliability Management, Vol. 27, No. 5, pp. 558-575.

Fresner J., Engelhardt G. (2004), "Experiences with integrated management systems for two small companies in Austria", Journal of Cleaner Production, Vol. 12, No. 6, pp. 623-631.

Geroski, P. (2000), “Models of technology diffusion”, Research Policy, Vol. 29, pp. 603-625.

Ghisellini, A., Thurston D. (2005), "Decision traps in ISO 14001 implementation process: case study results from Illinois certified companies", Journal of Cleaner Production, Vol. 13, pp. 763-777. 
Gurbaxani, V. (1990), "Diffusion in computer networks: the case of bitnet", Communications of the ACM, Vol. 33, No. 12, pp. 65-75.

Hardjono, T., Ten Have, S., Ten Have, W. (1997), "Cost and Benefits of ISO 9000 series: a practical study", International Journal of Quality \& Reliability, Vol. 16, No. 7, pp. 675-691.

Harrington D., Akehurst, G. (2000). An empirical study of service quality implementation. The Service Industries Journal, 20(2), 133-156.

ICTE (2010), Entidades certificadas. Available in www.calidadturistica.es. Accessed September 15,2010

IET 2011. Balance del Turismo. Año 2010. Available in http://www.iet.tourspain.es/informes/documentacion/FronturFamilitur/Balance\%20del\%20tu rismo\%20en\%20Espana\%20en\%202010.pdf . Revised in May, 10, 2011.

ISO (2003), The ISO survey of ISO 9000 and ISO 14000 Certifications: 12th cycle, ISO, Geneva, http://www.iso.ch/iso/en/iso9000-14000/iso9000/survey12thcycle.pdf. Accessed September 9, 2010.

ISO (2004), The ISO survey of ISO 9000 and ISO 14000 Certifications: 13th cycle, ISO, Geneva, http://www.iso.ch/iso/en/iso9000-14000/iso9000/survey13thcycle.pdf. Accessed September 9, 2010.

ISO (2005), The ISO survey of ISO 9000 and ISO 14000 Certifications: 14th cycle, ISO,

Geneva, http://www.iso.ch/iso/en/iso9000-14000/iso9000/survey14thcycle.pdf. Accessed September 9, 2010.

ISO (2006), The ISO survey of ISO 9000 and ISO 14000 Certifications: 15th cycle, ISO, Geneva, http://www.iso.ch/iso/en/iso9000-14000/iso9000/survey15thcycle.pdf. Accessed September 9, 2010. 
ISO (2007), The ISO survey of ISO 9000 and ISO 14000 Certifications: 16th cycle, ISO,

Geneva, http://www.iso.ch/iso/en/iso9000-14000/iso9000/survey16thcycle.pdf. Accessed September 9, 2010.

ISO (2008), The ISO survey of ISO 9000 and ISO 14000 Certifications: 17th cycle, ISO,

Geneva, http://www.iso.ch/iso/en/iso9000-14000/iso9000/survey17thcycle.pdf. Accessed September 9, 2010.

ISO (2009), The ISO survey of ISO 9000 and ISO 14000 Certifications: 17th cycle, ISO, Geneva, http://www.iso.ch/iso/en/iso9000-14000/iso9000/survey18thcycle.pdf. Accessed September 9, 2010.

Karapetrovic, S., Casadesús, M. (2009), "Implementing environmental with other standardized management systems: Scope, sequence, time and integration", Journal of Cleaner Production, Vol. 17, No. 5, pp. 533-540.

Kim, D., Lehtob, X., Morrison A. (2007), "Gender differences in online travel information search: Implications for marketing communications on the internet", Tourism Management, Vol. 28, pp. 423-433.

Kumar, Y., Sarkar, R., Swami, S. (2009), "Cluster-based diffusion: aggregate and disaggregate level modelling", Journal of Advances in Management Research, Vol. 6, No. 1, pp. 8-26.

Labodová, A. (2004), "Implementing integrating management systems using a risk analysis based approach", Journal of Cleaner Production, Vol. 12, No. 6, pp. 571-80.

Leung, H., Chan, K., Lee, T. (1999), “Cost and Benefits of ISO 9000 series: a practical study”, International Journal of Quality \& Reliability Management, Vol. 7, No. 7, pp. 77-91.

Llach, J., Marimon, F., Bernardo, M. (2011), "ISO 9001 diffusion analysis according to activity sectors", Industrial Management \& Data Systems, 111, n², 298-316.

Loch, C., Huberman B. (1999), "A punctuated-equilibrium model of technology diffusion", Management Science, Vol. 45, No. 2, pp. 160-178. 
MacVaugh, J., Schiavone, F. (2010), "Limits to the diffusion of innovation. A literature review and integrative model", European Journal of Innovation Management, Vol. 13, No. 2, pp. $197-221$.

Magd, H., Curry, A. (2003), "An empirical analysis of management attitudes towards ISO 9001:2000 in Egypt", The TQM Magazine, Vol. 15, No. 6, pp. 381-390.

Mahajan, V., Muller, E., Bass, F. (1990), "New product diffusion models in marketing: a review and direction for future research2, Journal of Marketing, Vol. 54, pp. 1-26.

Mahajan, V., Muller, E., Bass, F. (1995), “Diffusion of new products: empirical generalizations and managerial uses", Marketing Science, Vol. 14, No. 3, Summer: G79-89.

Marimon, F., Casadesús, M., Heras, I. (2006), "ISO 9000 and ISO 14000 standards: An international diffusion model", International Journal of Operations and Production Management, Vol. 26, No. 2, pp. 141-165.

Marimon, F., Casadesús, M., Heras, I. (2009), "ISO 9000 and ISO 14000 standards: A projection model for the decline phase", Total Quality Management \& Business Excellence, Vol. 20, No. 1, pp. 1-21.

Molina-Azorín, J.F., Claver-Cortés, E., Pereira-Moliner, J., Tarí, J.J., (2009). “Environmental practices and firm performance: an empirical analysis in the Spanish hotel industry”. Journal of Cleaner Production, Vol17, pp. 516-524.

Nield, K., Kozak, M. (1999), "Quality certification in the hospitality industry", Cornell Hotel and Restaurant Administration Quarterly, Vol. 40, No. 2, pp. 40-52.

O’Connor, P., Frew, A. (2002), “The future of hotel electronic distribution: Expert and industry perspectives", Cornell Hotel and Restaurant Administration Quarterly, Vol. 43, No. 3, pp. $33-45$. 
Pereira-Moliner, J., Claver-Cortés E., Molina-Azorín, J. (2010), "Strategy and Performance in the Spanish Hotel Industry", Cornell Hotel and Restaurant Administration Quarterly, Vol.51, No. 4, pp. 513-528.

Polsinka, B., Dahlgaard, J., Antoni, M. (2003), “The state of ISO 9000 certification: a study of Swedish organizations", The TQM Magazine, Vol. 14, No. 5, pp. 297-306.

Prakash, A., Potoski, M. (2007), "Investing Up: FDI and the Cross-Country Diffusion of ISO 14001 Management Systems”, International Studies Quarterly, Vol. 51, pp. 723-744.

Rodríguez-Antón, J., Alonso-Almeida, M. (2010), "Quality certification systems and their impact on employee satisfaction in services with high levels of customer contact", Journal of Total Quality Management and Business Excellence, Vol. 22, nº 1-2, pp. 145-158.

Rodríguez-Antón, J. M., Alonso-Almeida, M.M., (2008). Organización y dirección de empresas hoteleras, ed. Síntesis, Madrid.

Rodríguez-Antón, J. M., Alonso-Almeida, M., Rubio-Andrada, L. (2008), “Quality management systems in tourism: the Spanish case", International Journal of Management Cases, Vol. 10, No. 3, pp. 198-211.

Rogers, E. (1995), Diffusion of Innovations. New York, NY: The Free Press.

Saraiva, P., Duarte, B. (2003), "ISO 9000: some statistical results for a worldwide phenomenon”, TQM \& Business Excellence, Vol. 14, No. 10, pp. 1169-1178.

Sampaio, P, Saraiva, P., Guimaraes, A. (2009), "ISO 9001 certification research: questions, answers and approaches", International Journal of Quality \& Reliability Management, Vol.26, No. 1, pp. 38-58.

Stoneman, P. (1995), Handbook of the Economics of Innovation and Technological Change. Oxford: Blackwell Handbooks in Economics 
Sumiani, Y., Haslinda, Y., Lehman, G. (2007), "Environmental reporting in a developing country: a case study on status and implementation in Malaysia", Journal of Cleaner Production, Vol. 15, pp. 895-901.

Susskind, A., Kaemar, M., Borhgrevink, C. (2007), "How organizational standards and coworker support improve restaurant service", Cornell Hotel and Restaurant Administration Quarterly, Vol. 48, No. 4, pp. 370-384.

Tari, J., Claver-Cortes, E., Pereira-Moliner, J, Molina, J. (2009), "Is it worthwhile to be a quality certified hotel? Evidence from Spain”, International Journal of Quality \& Reliability Management, Vol.26, No. 9, pp. 850-864.

Taylor, W. (1995), "Organizational differences in ISO 9000 implementation practices", International Journal of Quality \& Reliability Management, Vol. 12, No. 7, pp. 10-27.

Teece, D. (1980), "The diffusion of an administrative innovation", Management Science, Vol. 26, No. 5, pp. 464-470.

Testa, M., Sipe, L. (2006), “A Systems Approach to Service Quality”, Cornell Hotel and Restaurant Administration Quarterly, Vol. 47, No. 1, pp. 36-51.

Tribe, J. (1999), Economía del ocio y el turismo. Madrid: Síntesis.

Vastag, G. (2003), Revisiting ISO 14000: A new "Look" at the drivers of certification. Working Paper, Indiana University.

WTO (2010), UNWTO World Tourism Barometer. Available in www.unwto.org. Accessed March 9, 2010.

Zutshi, A., Sohal, A. (2005), "Integrated management system. The experience of three Australian organisations", International Journal of Quality and Reliability Management, Vol. 16, No. 2, pp. 211-232. 
Table 1. Main characteristics of international standards and ' $Q$ ' standard

\begin{tabular}{|c|c|c|}
\hline Concepts & ISO 9001:2008 and ISO 14001:2004 & $\begin{array}{l}\text { Spanish Tourist Quality } \\
\text { Trademark }(Q)\end{array}$ \\
\hline Objective & $\begin{array}{l}\text { Quality assurance and environmental } \\
\text { management system }\end{array}$ & $\begin{array}{l}\text { Quality and service } \\
\text { standardization system }\end{array}$ \\
\hline Implementation & $\begin{array}{l}\text { The designed QMS ensures and maintains } \\
\text { quality levels }\end{array}$ & $\begin{array}{l}\text { The designed QMS is a } \\
\text { self-diagnosis tool }\end{array}$ \\
\hline Documentation & Powerful documentation system & Light documentary system \\
\hline $\begin{array}{l}\text { Decision-makin } \\
\text { g }\end{array}$ & $\begin{array}{l}\text { Service levels are strategic decisions } \\
\text { undertaken } \\
\text { by management }\end{array}$ & $\begin{array}{l}\text { All quality and service } \\
\text { specifications included in the } \\
\text { standard itself }\end{array}$ \\
\hline $\begin{array}{l}\text { Organization's } \\
\text { characteristics }\end{array}$ & Applicable to any industry and organization & Focused on tourist activity \\
\hline Quality level & $\begin{array}{l}\text { No specific quality level guaranteed, but } \\
\text { service is adjusted to level of specifications } \\
\text { set out by the establishment itself }\end{array}$ & $\begin{array}{l}\text { Provides information about } \\
\text { required quality level, which } \\
\text { might influence clients' } \\
\text { purchasing decisions }\end{array}$ \\
\hline $\begin{array}{l}\text { Environmantal } \\
\text { Management }\end{array}$ & & $\begin{array}{l}\text { Provide rules for } \\
\text { environmental management } \\
\text { of the establishment }\end{array}$ \\
\hline
\end{tabular}

Source: Adapted from Casadesus et al. (2010) 
Table 2. Number of ISO 9001 certifications for 'hotels and restaurants' sector 1998-2008 (global and Spain)

\begin{tabular}{lccccccccccc}
\hline Year & 1998 & 1999 & 2000 & 2001 & 2002 & 2003 & 2004 & 2005 & 2006 & 2007 & 2008 \\
\hline $\begin{array}{l}\text { ISO 9001 certificates at } \\
\text { worldwide scale }\end{array}$ & 865 & 1,794 & 1,187 & 1,391 & 1,857 & 2,391 & 2,924 & 3,557 & 3,875 & 4,186 & 3,437 \\
\hline $\begin{array}{l}\text { ISO 9001 certificates in } \\
\text { Spain }\end{array}$ & & & 69 & 121 & 169 & 287 & 390 & 416 & 487 & 504 & 541 \\
\hline
\end{tabular}

(*) European Accreditation code number 30

Source: Compiled from ISO (2003, 2004, 2005, 2006, 2007, 2008, and 2009) and Forum Calidad (2001, 2002, 2003, 2005, 2006, 2007, 2008, and 2009). 
Table 3. Number of ' $Q$ ' certificates by sub-sectors and aggregated for sub-sectors $2,3,5,6$, 11, and 15 (Spain, 1998-2009)

Q certifications

\begin{tabular}{|c|c|c|c|c|c|c|c|c|c|c|c|c|c|}
\hline Codes & by subsectors & 1998 & 1999 & 2000 & 2001 & 2002 & 2003 & 2004 & 2005 & 2006 & 2007 & 2008 & 2009 \\
\hline 2 & $\begin{array}{l}\text { Rural } \\
\text { Accommodations }\end{array}$ & & 2 & 4 & 16 & 20 & 34 & 46 & 60 & 82 & 114 & 172 & 227 \\
\hline 3 & Small Residences & & & & & & & & 2 & 3 & 4 & 6 & 7 \\
\hline 5 & Spas & & & & & & & & 4 & 15 & 20 & 28 & 31 \\
\hline 6 & Campings & & & & 3 & 4 & 6 & 8 & 10 & 12 & 15 & 19 & 21 \\
\hline 11 & $\begin{array}{l}\text { Hotels and } \\
\text { Apartments }\end{array}$ & 11 & 50 & 71 & 97 & 132 & 154 & 195 & 244 & 357 & 400 & 461 & 522 \\
\hline 15 & Restaurants & & & & 8 & 17 & 29 & 35 & 47 & 61 & 80 & 135 & 196 \\
\hline & Total & 11 & 52 & 75 & 124 & 173 & 223 & 284 & 367 & 530 & 633 & 821 & 1,004 \\
\hline
\end{tabular}

Source: Compiled from ICTE (1999, 2000, 2001, 2002, 2003, 2004, 2005, 2006, 2007, 2008, 2009, 2010) 
Figure 1. Number of ' $Q$ ' certifications (Spanish tourism sector) (2000-09)

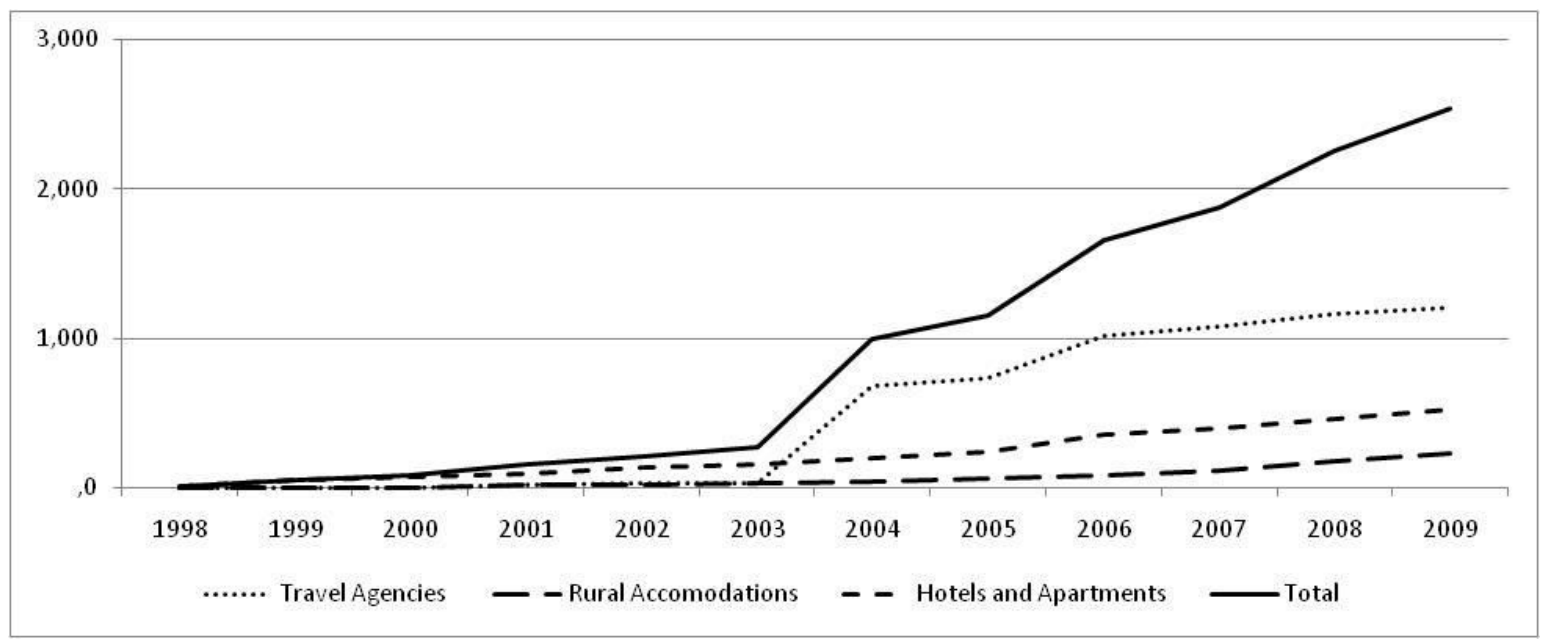

Source: ICTE (2010) 
Figure 2. Logistic curves and forecast of certifications for ISO 9001 and ISO 14001 worldwide

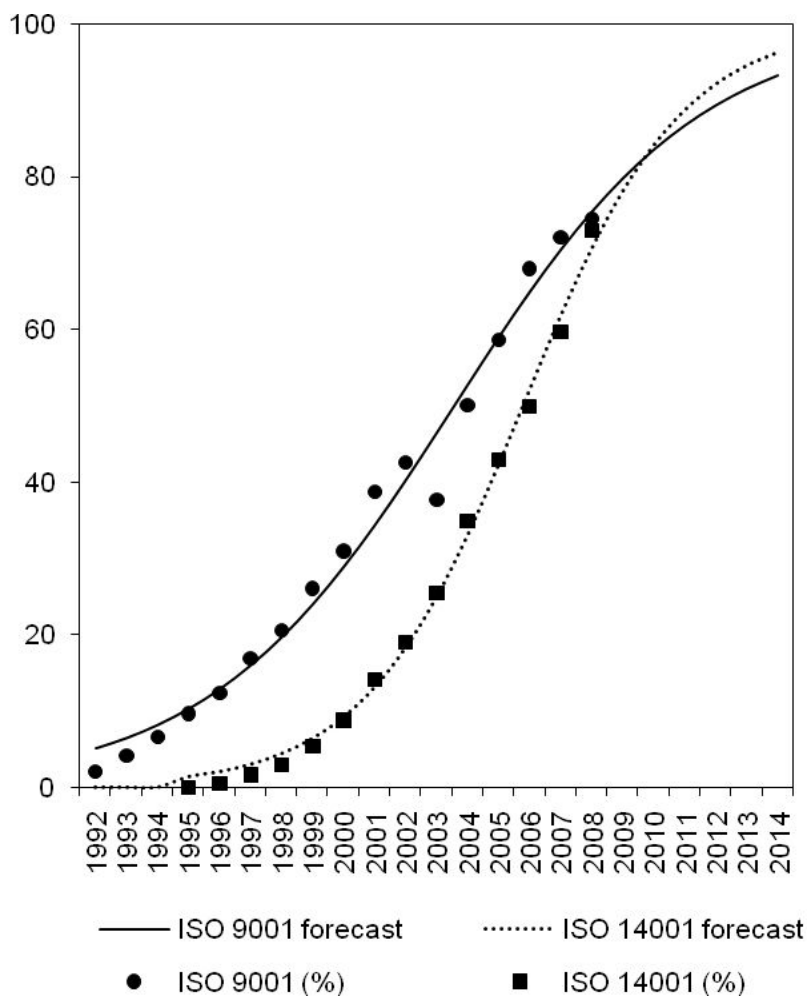

\begin{tabular}{|c|c|c|c|c|c|c|}
\hline \multicolumn{7}{|c|}{ Forecast of ISO certificates worldwide considering the logistic curve. } \\
\hline & \multicolumn{3}{|c|}{ ISO 9001} & \multicolumn{3}{|c|}{ ISO 14001} \\
\hline & \multicolumn{2}{|l|}{ DF } & Sum Sq & \multicolumn{2}{|l|}{$\mathrm{DF}$} & Sum Sq \\
\hline Regression & 3 & & $4.97 \mathrm{E} 12$ & \multicolumn{2}{|l|}{3} & $1.06 \mathrm{E} 11$ \\
\hline Residual & \multicolumn{2}{|l|}{14} & $2.59 \mathrm{E} 10$ & \multicolumn{2}{|l|}{14} & $1.97 \mathrm{E} 8$ \\
\hline Uncorrected Total & \multicolumn{2}{|l|}{17} & $4.99 \mathrm{E} 12$ & \multicolumn{2}{|l|}{17} & $1.06 \mathrm{E} 11$ \\
\hline (Corrected total) & 16 & & $1.65 \mathrm{E} 12$ & 16 & & $5.07 \mathrm{E} 10$ \\
\hline \multirow[t]{2}{*}{ R squared } & \multicolumn{3}{|c|}{.991} & \multicolumn{3}{|c|}{.998} \\
\hline & Value & LL & UL & Value & LL & UL \\
\hline $\mathrm{N}_{0}$ & $67,318.27$ & $39,445.29$ & $95,191.25$ & $3,592.96$ & $1,975.52$ & $5,210.40$ \\
\hline $\mathrm{K}$ & $1,318,424.35$ & $163,492.09$ & $1,699,080.01$ & $258,940.32$ & $207,751.70$ & $310,128.95$ \\
\hline$\overline{r_{0}}$ & .25 & .19 & .31 & .40 & .33 & .46 \\
\hline
\end{tabular}

Source: Casadesus et al., (2011) 
Figure 3.- Logistic curve and forecast of ISO 9001 certifications for "Hotels and restaurants" sector worldwide

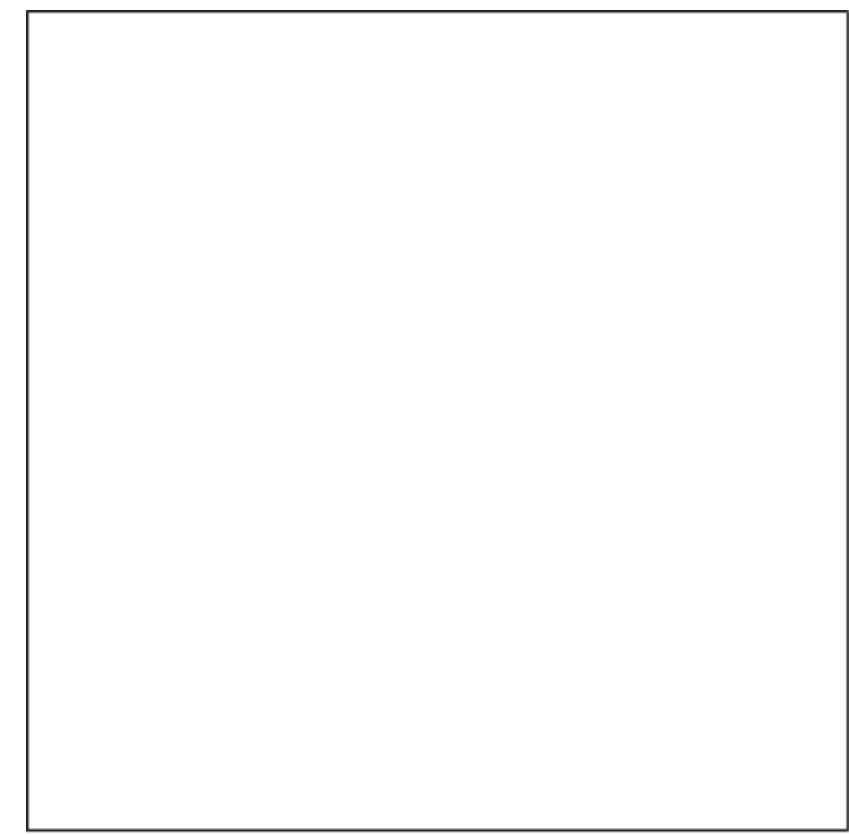

\begin{tabular}{|l|c|c|}
\hline & \multicolumn{2}{|c|}{ Hotels and restaurants } \\
\hline & Sum Sq & DF \\
\hline Regression & $6.69 \mathrm{E} 7$ & 3 \\
\hline Residual & 104,866 & 6 \\
\hline Uncorrect Total & $6.70 \mathrm{E} 7$ & 9 \\
\hline (Corrected total) & $1.21 \mathrm{E} 7$ & 8 \\
\hline R squared & \multicolumn{2}{|c|}{.984} \\
\hline & Value & Standard error \\
\hline $\mathrm{N}_{0}$ & 665.62 & 84.38 \\
\hline $\mathrm{K}$ & $5,835.19$ & 769,85 \\
\hline $\mathrm{r}_{0}$ & .34 & .45 \\
\hline
\end{tabular}

Source: Compiled from ISO (2003, 2004, 2005, 2006, 2007, 2008, 2009) 
Figure 4.- Logistic curve and forecast of Spanish $Q$ certifications

FORECAST OF Q CERTIFICATES

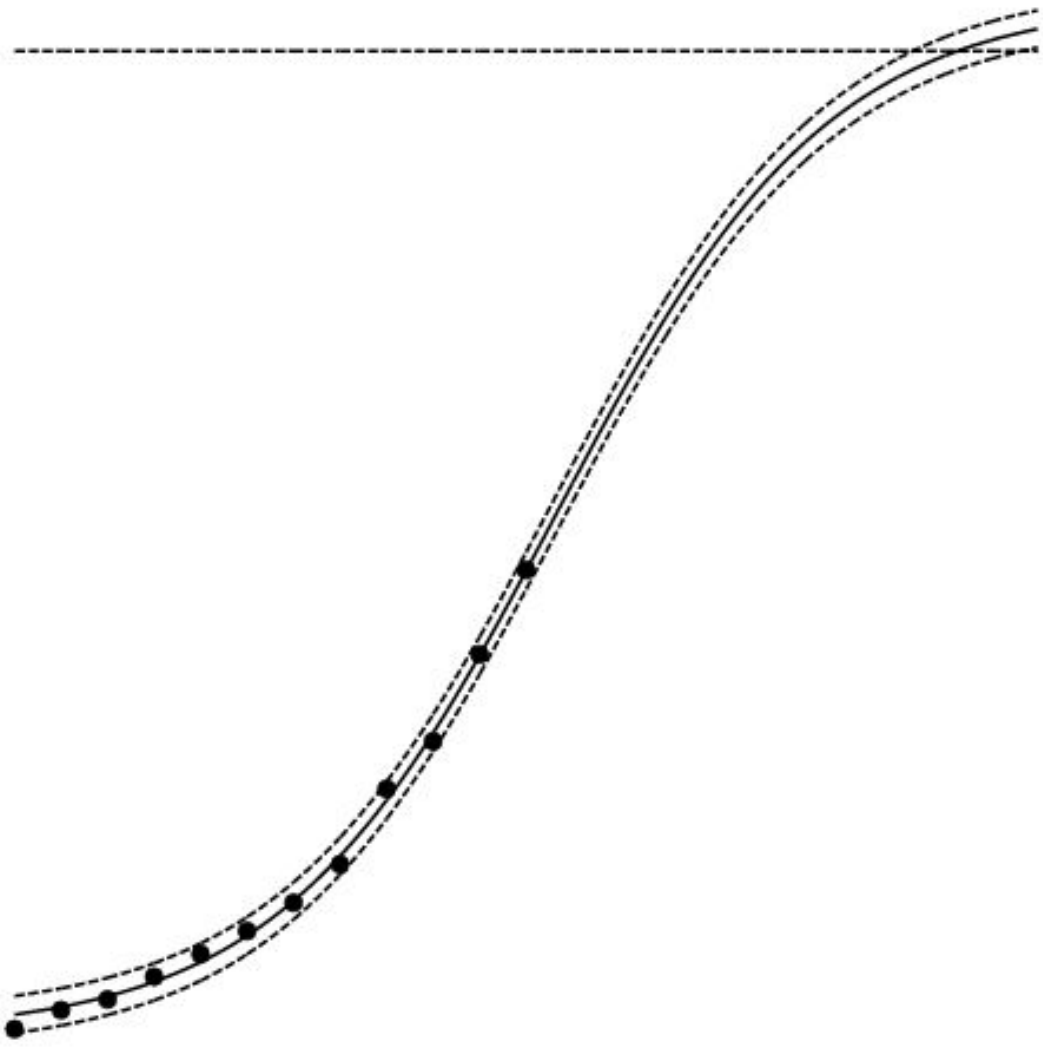

\begin{tabular}{|l|c|c|}
\hline & \multicolumn{2}{|c|}{ Spanish Q standard } \\
\hline & Sum Sq & DF \\
\hline Regression & $2.68 \mathrm{E} 6$ & 3 \\
\hline Residual & 2,839 & 9 \\
\hline Uncorrect Total & $2.68 \mathrm{E} 6$ & 12 \\
\hline (Corrected total) & $1.14 \mathrm{E} 6$ & 11 \\
\hline R squared & \multicolumn{2}{|c|}{.998} \\
\hline & Value & Standard error \\
\hline $\mathrm{N}_{0}$ & 42.12 & 5.24 \\
\hline $\mathrm{K}$ & $2,237.15$ & 421,60 \\
\hline $\mathrm{r}_{0}$ & .34 & .02 \\
\hline
\end{tabular}

Source: Compiled from ICTE (2010) 
Figure 5. Comparison between diffusion models of "hotels and restaurants" sector of ISO 9001 and Spanish Q standard

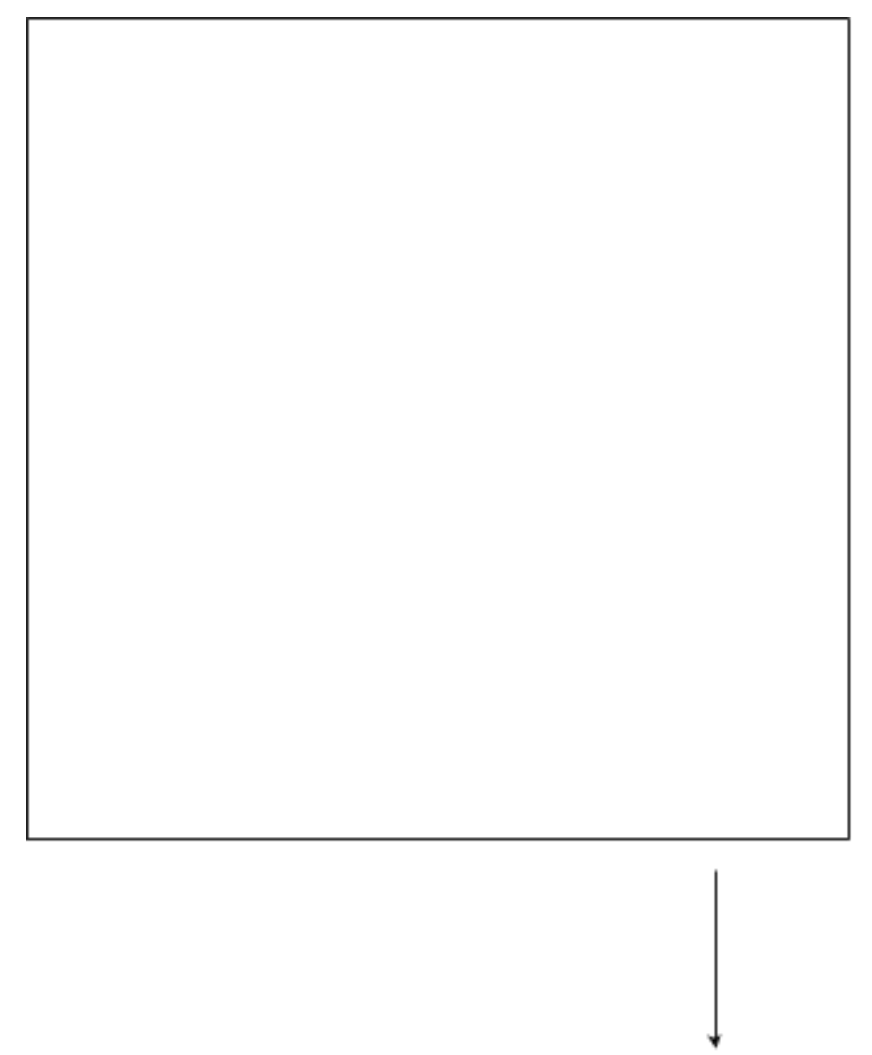

\begin{tabular}{|l|c|c|c|c|}
\hline & \multicolumn{2}{|c|}{ Spanish Q standard } & \multicolumn{2}{c|}{ ISO 9001 (Hotels and restaurants in Spain) } \\
\hline & Sum Sq & DF & Sum Sq & DF \\
\hline Regression & $2.68 \mathrm{E6}$ & 3 & $1,237,615$ & 3 \\
\hline Residual & 2,839 & 6 & 1,738 & 9 \\
\hline Uncorrect Total & $2.68 \mathrm{E} 6$ & 8 & $1,239,354$ & 12 \\
\hline (Corrected total) & $1.14 \mathrm{E} 6$ & 8 & 249,992 & 11 \\
\hline R squared & \multicolumn{2}{|c|}{.998} & \multicolumn{2}{c|}{.993} \\
\hline & Value & Standard error & Value & Standard error \\
\hline $\mathrm{N}_{0}$ & 42.12 & 9.368 & 65.76 & 5.24 \\
\hline $\mathrm{K}$ & $2,237.15$ & 17.658 & 546.20 & 421.60 \\
\hline $\mathrm{r}_{0}$ & .34 & .062 & .68 & .02 \\
\hline
\end{tabular}

Source: Compiled from ISO (2009) and ICTE (2010) 
